THURSDAY, OCTOBER 26, I899.

\section{THE INTERNATIONAL ASSOCIATION OF ACADEMIES}

$\mathrm{O}^{\mathrm{r}}$ $F$ late there has been much activity in matters which require the co-operation of scientific men of different nationalities. The International Catalogue of Scientific Literature has been the subject of several conferences. The International Meteorological Conference and the Bureau International des Poids et Mésures are samples of different types of organisations which are both numerous and useful.

The exchange of courtesies at Dover between the British and French Associations for the Advancement of Science gave another proof that cosmopolitanism is growing in strength in the scientific world, and can assert itself even when the political atmosphere is not unclouded.

A still more striking instance of the same fact will be found in the account which we give in another column of a conference at which the possibility of founding an International Association of the great Academies of the world was discussed by their representatives.

The details of the plan are, we believe, still under consideration, but enough has been done to make it practically certain that the Association will be founded, and that the Royal Society, the Academies of Science of France, of Berlin, St. Petersburg, Vienna, Rome, Washington and other similar bodies will be brought into formal relations with each other. It is, no doubt, open to pessimists to say that international meetings are now too numerous, but we venture to think that the proposal to bring about formal conferences between the principal scientific bodies in the world is most important, and that the meetings are likely to lead to more permanent results than do gatherings (also useful in their way) from which the picnic element is not altogether eliminated.

On the other hand, an Association of Academies will be a more flexible instrument for good than are international organisations appointed for specific purposes, and composed either of persons named by the Governments of the countries represented, or of officials controlling national observatories.

The Committee of the Bureau International des Poids et Mésures in Paris and the Geodetic Conference at Berlin are examples of bodies which are entrusted with strictly defined duties, and cannot travel outside the lines laid down for them by their respective Governments. A union of Academies would, however, bring about the meeting at stated intervals of representatives of science, who would not be fettered by the official ties which must necessarily restrict the action of Government nominees. It would thus be possible for the associated Academies to discuss questions connected with any branch of science which might in their opinion call for international co-operation, and if they decided that such action was desirable, to take steps to call the attention of the scientific world or of the various Governments to the necessity for united action.

The Association would, in fact, enjoy the same freedom as the Council of the Royal Society, while it would be able to bring to bear on any question the mature opinion of representatives of the whole scientific world.

It is obvious that an Institution founded on these lines may become of the very first importance, and may play the part of an international parliament of science. Whether or no such a hopeful forecast is realised, it cannot but be useful that the centres of scientific organisation in different countries should themselves be organised, and should be united-not merely by common interests, or by the bonds of friendship which have been established between many of their members-but by formal links which will enable them to take united action when such action is required.

As some of the foreign Academies are concerned with literature and philosophy as well as with natural science the Association will be based upon the same lines. The two sections into which it will be divided will, however, be almost entirely independent, and no serious difficulty need be anticipated on this score. It is, however, curious that though both of the great Anglo-Saxon nations possess important societies concerned with the cultivation of different branches of literature, history or philosophy, neither of them has developed an institution the breadth of whose aims would warrant its inclusion in a list of Acadenies of literature. It will be unfortunate if this fact makes the literary section of the new Association less truly representative than that which will be concerned with natural science.

"An academy quite like the French Academy... we shall hardly have, and perhaps we ought not to wish to have it," said Matthew Arnold, but it will be interesting to see if the foundation of an International Association of Academies leads to a rearrangement of existing organisations which might give us in England something corresponding to the "Académie des Inscriptions et Belles-Lettres," or to the "Académie des Sciences Morales et Politiques."

\section{A PIONEER IN TELEGRAPHY.}

The Life Story of the late Sir Charles Tilston Bright; with which is incorporated the Story of the Atlantic Cable and the First Telegraph to India and the Colonies. By his Brother, Edward Brailsford Bright, and his Son, Charles Bright. Pp. xix +506 , and xi + 701. (Westminster: A. Constable and Co.)

TWO books have recently appeared dealing with tele1 graphy from shore to shore, the one on "Submarine Telegraphs" from the pen of Mr. Charles Bright alone, the other the two-volume treatise now under review. Both are somewhat lengthy, the former because the description of "Submarine Telegraphs" was so much bound up with details concerning the life of Sir Charles Bright, and the latter because to the "Life Story of the late Sir Charles Bright" has been added so much about the history of submarine telegraphy.

Leaving the accounts of the ancestors of this family which are given in rather bewildering detail, we come to the boyhood and youth of the two brothers Charles and Edward. Charles at fifteen, and Edward at sixteen, entered the service of the Electric Telegraph Company soon after its formation in 1847 , and started on their careers as inventors. In 1849 they devised a method

$$
\text { No. I } 56.5 \text {, vol. 60] }
$$

